Silvia Suteu*

\title{
Special Topic: The Romanian Constitution at 25 - A Critical Examination of Romanian Constitutionalism
}

https://doi.org/10.1515/icl-2017-0065

2016 marked the $25^{\text {th }}$ anniversary of the Romanian Constitution, as well as 150 years since the passing of Romania's first modern constitution in 1866. While these milestones attracted some attention within the country itself, ${ }^{1}$ Romanian constitutionalism remains something of an unknown internationally. Romanian constitutional developments have often been ignored or marginalized in volumes on the evolution of constitutionalism in the region. ${ }^{2}$ The foundational story of Romania's post-1989 constitution has also yet to be told, particularly to an international audience, having thus far been sketched only in the most cursory terms and often without access to primary sources. ${ }^{3}$ The situation has been somewhat better in collections on European Union (EU) accession, although there the emphasis has tended to remain on European integration measures and has not extended to discussing Romanian constitutionalism on its own terms. ${ }^{4}$

To an extent, this state of affairs could be attributed to a lack of expertise and to the scarcity of Romanian voices in comparative constitutional law. Another potential explanation is that the focus of much of this writing has been on fundamental rights protection and constitutional review; given the

1 Lavinia Stan and Diane Vancea (eds), Post-Communist Romania at Twenty-Five: Linking Past, Present and Future (Lexington Books 2015).

2 Wojciech Sadurski, Rights Before Courts: A Study of Constitutional Courts in Postcommunist States of Central and Eastern Europe (Springer 2005) and Wojciech Sadurski et al, Rethinking the Rule of Law after Communism (CEU Press 2005).

3 Rett R. Ludwikowski, Constitution-making in the Region of Former Soviet Dominance (Duke U Press 1996) and Laurel Miller and Louis Aucoin (eds), Framing the State in Times of Transition: Case Studies in Constitution Making (USIP 2010).

4 Wojciech Sadurski, Constitutionalism and the Enlargement of Europe (Oxford U Press 2012) and Kyriaki Topidi and Alexander Morawa (eds), Constitutional Evolution in Central and Eastern Europe: Expansion and Integration in the EU (Routledge 2010).

*Corresponding author: Silvia Suteu, Lecturer in Public Law, University College London, London WC1H 9BT, UK, E-mail: s.suteu@ucl.ac.uk 
Romanian Constitutional Court's timid first few years, together with a lacunar judgment style and dearth of available translations, its emerging jurisprudence has not attracted much outside interest. Finally, many of the writings in question have simply assumed that explanations developed in the case of other countries in the region - notably Hungary and Poland - could be applied to Romanian constitutional law.

This special topic (in this and the ICL Journal's next issue) aims to challenge such assumptions by critically examining the evolution of Romania's Constitution in the quarter century since its adoption. It does so through the lens of the constitution's relationship to three of its 'others': national minorities, citizens as empowered actors in the constitutional reform process, and women. ${ }^{5}$ To these is added a fourth institutional 'other': the country's embattled Constitutional Court. The first three articles discuss: the exclusionary nature of part of the Constitution's eternity clause; the rise of citizen participation; and the limits of gender equality guarantees. The fourth article traces the evolution of the Romanian Constitutional Court from a peripheral actor to a more confident player in the legal system. The collection thus proposes these four axes as the lines along which to trace the maturing of one of the most understudied postCommunist constitutions. The special topic's originality rests in the critical lens it brings to its subject matter, together with an unapologetic belief that studying Romanian constitutionalism is both worthwhile and likely to enrich and yield different results than the study of neighboring constitutional systems.

Emerging from the four articles are several points of commonality. First, they all illustrate the interplay between law and politics in the Romanian constitutional environment. Whether it be the constitutional nationalist project behind the constitution's eternity clause; the participatory turn in constitutional reform and its relationship to constitutional politics; the fraught battle for constitutional recognition of gender equality; or the intense politicization of the Constitutional Court in its early years - all articles emphasize the inevitable overlap between the legal and the political in the evolution of the Romanian Constitution.

Second, the articles confirm the significant constitutional impact of international actors in the region, in particular the EU and Council of Europe. SelejanGutan (issue 4/2017) emphasizes the positive role played by the EU's justice monitoring mechanism and by the European Court of Human Rights. Suteu

5 The authors took inspiration from the theme of the 2016 ICON-S conference, 'Borders, Otherness and Public Law' https://icon-society.org/previous-conferences/2016-conference/, in their focus on constitutionalism and 'the other'. They would like to thank the participants in that event for their valuable comments. 
(issue 3/2017) and Brodeala (issue 4/2017) show how external actors were only partially successful in pushing for deeper constitutional accommodation of national minorities and women, respectively. Blokker (issue 3/2017) illustrates how such actors have a say even within participatory reform processes, as the Venice Commission did when reviewing the constitutional amendment draft in 2014. That European institutions have acted as normative actors in the region generally, and in Romania especially, is not novel, ${ }^{6}$ yet the articles here trace previously understudied processes and highlight both the benefits and the limitations of such international involvement.

Third, the articles reveal the ebb and flow of the Romanian Constitution's embeddedness in society. Suteu's reveals how constitutional provisions which enshrine a vision of society as a monolith exclude minorities and silence more pluralist voices. Brodeala calls for more progressivism in constitutional provisions on gender equality, thereby expecting the Romanian Constitution to finally leave behind its Socialist origins and truly bring about social change in the sphere of gender relations. By looking at constitutional processes designed to bring the constitution closer to the people, Blokker offers an optimistic view of how the Romanian fundamental law could overcome its elitist beginnings. Selejan-Gutan also describes variations in perceptions of the Constitutional Court, both among citizens and political actors, an institution whose role in the constitutional system has evolved from its timorous early days.

Fourth and finally, the articles show once more how important context is when engaging in constitutional analysis. All authors discuss the Romanian case as an illustration of a country aiming to transition to mature democratic practices and robust rule of law protections, as well as one firmly rooted in the Central and Eastern European post-Communist context. Suteu and Brodeala identify continuities between the Romanian Constitution and the Communist regime's nationalist and women's rights restrictive policies, respectively. Blokker militates for recognition of Romania's comparative significance in the burgeoning field of participatory democracy experimentation. Selejan-Gutan, meanwhile, adds to the literature on constitutional courts in new democracies ${ }^{7}$ and uses the Romanian case study to exemplify the tightrope these institutions must walk during transitional periods.

6 Armin von Bogdandy and Pal Sonnevend, Constitutional Crisis in the European Constitutional Area: Theory, Law and Politics in Hungary and Romania (Hart/Beck 2015) and Iulia Motoc and Ineta Ziemele, The Impact of the ECHR on Democratic Change in Central and Eastern Europe: Judicial Perspectives (Cambridge University Press 2016).

7 Samuel Issacharoff, Fragile Democracies: Contested Power in the Era of Constitutional Courts (Cambridge University Press 2015). 
The broader objective of this collection is to align itself with a new generation of constitutional scholars working towards putting the spotlight on Romania on its own terms. ${ }^{8}$ This special topic thus aims to contribute to this fresh scholarly momentum in the study of the Romanian Constitution and to firmly place it on the map of constitutional analysis in the region.

8 Among these, Selejan-Gutan has previously provided a contextual analysis of the Romanian Constitution unique in its breadth. Perju and Iancu have provided much-needed clarity on constitutional conflicts to do with institutional arrangements and the balance of powers in the Romanian Constitution. Parau has studied Romanian constitutional history in a transnational context. The area of constitutional politics has seen the likes of Blokker, Gherghina, Hein and Miscoiu push for the recognition of the specificity of Romanian constitutional culture, not least in innovative areas such as participatory constitutional reform and deliberative lawmaking. See: Bianca Selejan-Gutan, The Constitution of Romania: A Contextual Analysis (Hart 2016); Vlad Perju, 'The Romanian Double Executive and the 2012 Constitutional Crisis' (2015) 13:1 International Journal of Constitutional Law 246; Bogdan Iancu, 'Separation of Powers and the Rule of Law in Romania: The Crisis in Concepts and Contexts' in von Bogdandy and Sonnevend (n 6) 153-169; Cristina Parau, 'Romania's Transnational Constitution: A Tradition of Elite Learning and Self-empowerment' in Denis Galligan and Mila Versteeg (eds), Social and Political Foundations of Constitutions (Cambridge University Press 2013) 497-531; Paul Blokker, New Democracies in Crisis? A Comparative Constitutional Study of the Czech Republic, Hungary, Poland, Romania and Slovakia (Routledge 2013); Sergiu Gherghina and Michael Hein, 'Romania' in Anna Fruhstorfer and Michael Hein (eds), Constitutional Politics in Central and Eastern Europe: From Post-Socialist Transition to the Reform of the Political System (Springer 2016) 172-197; Sergiu Gherghina and Sergiu Miscoiu, 'Crowd-Sourced Legislation and Politics: The Legitimacy of Constitutional Deliberation in Romania' (2016) 63:1 Problems of Postcommunism 27. 